\title{
Problematising 'Indigeneity' through Hansda Sowvendra Shekhar's The Mysterious Ailment of Rupi Baskey
}

\author{
Amitayu Chakraborty \\ Assistant Professor, Department of English, Durgapur Women's College, \\ West Bengal, India. ORCID: oooo-ooo3-3999-448X. amitayuc@yahoo.com;
}

\begin{abstract}
The article problematises dominant discourses on 'indigeneity' (within the context of India) through an analysis of the novel The Mysterious Ailment of Rupi Baskey (2014) written by Hansda Sowvendra Shekhar (1983-). Those discourses are predicated on colonial and neocolonial ethnic stereotypes: at times 'the indigenous' denotes a reluctant subject of the nation-state, a primitive mindlessly opposing the 'modernising' corporate projects; at times, it constitutes a pristine innocence, an antithesis of the 'corrupting' urban life. Santhals, among various other indigenous communities in India, have been a victim of such reductivism. The article argues that Hansda's novel offers a nuanced depiction of a Santhal community in India which is fraught with internal conflicts as well as external threats undercutting the grand narrative in which the adivasi is a cultural imaginary, either an embodiment of atavism and wildness to be curbed or vulnerable artefacts to be preserved. The tale of Rupi appears to be a critical departure from the monolithic images of adivasis as it blends the magical with the real.
\end{abstract}

Keywords: indigeneity, Santhal, adivasi, tribe, magical realism, subaltern, Hansda Sowvendra Shekhar.

\section{Introduction}

The ontology of adivasis or indigenes is a fault line in the Indian nation-state's narrative of teleological progress. Definitions and representations of the so-called indigenous people are fraught with semantic ambiguity and power politics. Sometimes 'the indigenous' denotes a recalcitrant subject of nation-state mindlessly opposing the 'modernising' corporate projects; sometimes it constitutes a prehistoric innocence, diametrically opposed to the 'corrupting' urban life. From the colonial era, or even before that, the large heterogeneous communities, who are presently clubbed together in India as 'Scheduled Tribes', have been suffering from essentialisation and reductivism. They have been tagged as animist 'tribes' (as opposed to Hindu 'castes') naturally prone to criminality and bestiality, on the one hand. On the other hand, they have been championed as an embodiment of autochthony and innocence. Neither colonial nor nationalist epistemological attempts seem capable of addressing the actual ontological crises of the so-called indigenous population. The more recent transnational interest in the rights of

(c) AesthetixMS 2019. This Open Access article is published under a Creative Commons Attribution Non-Commercial 4.0 International License (http://creativecommons.org/licenses/by-nc/4.o/), which permits non-commercial re-use, distribution, and reproduction in any medium, provided the original work is properly cited. For citation use the DOI. For commercial re-use, please contact editor@rupkatha.com. 
indigenous people aims to ameliorate their position but, at least in India, ends up reinvigorating colonial stereotypes. This article addresses this issue of the indigenous people of India through an exploration of a work of magical realism, namely The Mysterious Ailment of Rupi Baskey: A Novel (2014), written by the Indian writer Hansda Sowvendra Shekhar (1983-), who won the Sahitya Akademi Yuva Puraskar for the novel. In the first section of the article, there is an attempt to historicise the above-mentioned problematic of adivasis. The second section explores the novel in detail in order to contend that Hansda's work is marked by a critical departure from the reductivist representations of adivasis. The article concludes that Hansda's novel subverts the discursive framework that colonises the indigenes of India.

\section{Exploring colonial and neocolonial discourses on indigeneity}

For anthropologists, the term 'indigeneity' implies identification and/or strong connections between a group and locality, and thus it has been distinguishing the 'natives' from the 'others' or 'foreigners' vis-à-vis the Americas for a long time. In the late twentieth century, the term received a crucial (primarily western) international attention through the 1957 and 1989 conventions of the International Labour Organization under the United Nations (Merlan, 2009, p. 303-304; Sanders, 1999, p. 4-6). In India, the dominant discourses on indigeneity are embedded in autochthony and primitivism, and associated with a state-sponsored demography of certain communities who are ostensibly known as 'tribes' or 'adivasis' or 'indigenous people'. Although these terms are often used interchangeably, they have different origins and progresses (Sen, 2017, p. 3-11; Bates \& Shah, 2017, p. 1-34; Rycroft \& Dasgupta, 2011, p. 1-13; Karlsson \& Subba, 2006, p. 2-9; Ghosh, 2006, p. 507509). It has been argued by many researchers that the term 'tribe' or 'tribal people' had its genesis in the lopsided colonial ethnography of the late nineteenth century and early twentieth century, which had been informed by the native upper-caste/brahmnical constructs, and that such colonial ethnography was instrumental in the establishment of two strong and broad ethnic categories: the Hindu caste and animist tribe (Bates 1995, p. 14; Skaria 1997, p. 726-732; Ghosh, 2006, p. 507; De, 2018, p. 2-17). As a part of its affirmative action, the post-colonial government of India constitutionally recognised many disadvantaged social groups as Scheduled Castes and Scheduled Tribes, and ensured certain privileges for them in education and employment in order to ameliorate for their historical deprivation by the majorities. Thus the term 'tribe' remains in currency in administrative, academic and day-to-day discourses. The term 'adivasi' came to prominence with the commencement of the Jharkhand movement in the 1930 s due to the protests for tribal rights held by the Chhotanagpur Unnati Samaj and the Adivasi Mahasabha, and with the progress of the movement in the post-independence period, 'adivasi' became a strong cultural imaginary that purported to consolidate a myth of unified tribal identity on the basis of an ethnosymbolic past (Ghosh, 2006, p. 505; This is Our Homeland, 2007, p. 84). However, determination of terminological aptness is beyond the scope of this article. Instead, using 'adivasi', 'indigenes', 'indigenous people' and 'tribe' interchangeably, the author of the article would focus the predicament of the so-called autochthones of India in order to underscore the relevance of Hansda's novel.

The people known as adivasis or indigenes in India have a protracted history of suffering and resistance. In the middle of the nineteenth century, there was a major change in colonial policies of the British in India: due to the rise of Utilitarian liberalism in England, British colonialists in India assumed paternalistic role vis-à-vis the 'uncivilised', 'brown' men, and focused more on governance and administration than military conquest (Mehta, 1999, p. 11; Avijit, 2018, p. 306). However, this transition was impeded by rebellions from the overstrung communities of the 
central and eastern India including Ho, Santhals, Bhils and Mundas, and it was the time (1840s onwards) when these communities started to demand a separate state for themselves (George, 2016, p. 276). From that time onwards, the British started to define, divide and rule over several Indian communities in accordance with its own administrative convenience (Avijit, 2018, p. 306307). Multiple layers of ethnicities crystallised as a result: castes (upper and lower) and tribes (criminal, noble, atavistic and so on) were segregated forever, and this segregation was predicated upon different "shades of wildness" (Skaria, 1997, p. 726-732). Ethnic stereotypes grew strong as the tribal was sometimes deemed to be atavistic and bestial, and hence to be coerced; sometimes noble reveller and possessor of primordial wisdom, and hence to be protected; sometimes highspirited autochthones protesting the white man's 'civilising' mission and so on (Avijit 2018; De 2018; Ghosh 2006; Heredia, 2016). Moreover, the discursive formation that was championed by the cultural nationalism of the Indian middle-class was a projection of the adivasi as a 'noble savage', an antithesis of colonial modernity (Banerjee, 2016, p. 2; Sen, 2018, p. 204). On the one hand, colonial administration moved towards territorial protection for tribes considering them to be primitive; on the other hand, contrary to their propagation of this primitive image, colonial capitalist modernity continuously made inroads into the ways of life of the so-called autochthones through the introduction of laws of the market and private property-and this was materialised through the nexus between colonial administration and native (elite) landholders, accountants, registrars, and watchmen (Collu, 1999, p. 47; Ghosh, 2006, p. 508; Heredia, 2016, p. 135). In so doing, colonial administration exploited, displaced and dispossessed several people belonging to such marginalised ethnicities.

One must also note the political backlash of this colonial oppression. During the last decade of colonial rule, many leaders of minority ethnic groups (such as Santhal, Munda and Bhil) proclaimed their autochthony by assuming the term 'adivasi', and they did this to claim their rights to land and forest, the territories which were rich in minerals and other natural resources. Interestingly, they claimed their legitimacy of ownership on the basis of precolonial and colonial symbolic pasts, especially on the basis of the colonial administrative move towards territorial protection for tribes (Sen, 2018, p. 192-194). This proclamation however did little to aid the actually disenfranchised, non-elite adivasis (Ghosh 2006, p. 505). Instead, it entailed a cultural quietism by bolstering an essentialist cultural politics formulated by elite adivasis such as Jaipal Singh Munda (Banerjee, 2006, p. 105). Tribal or adivasi culture became a monolithic bloc that resided on the fringes of the mainstream Indian society. The following words of Prathama Banerjee are pertinent to this context:

'Tribal' culture itself here would be seen as a culture of subversive, marginal politics, not quite shared by mainstream Indian society-played out through cultural symbols of struggle and solidarity, like the bow and arrow, like the 'tribal' dance or through names like Sidhu, Kanu and Birsa. The repeated fissures that the Jharkhand Party went through and the criticisms it faced from other Adivasi political formations-like the Birsa Seva Dal, the All India Sidhu Kanhu Baisi and even early Jharkhand Mukti Morcha-through the 1960 s and 7os was based precisely on this radical and rebellious 'tribal' tradition which sought to reinvent what appeared as the natural political militancy of Adivasi culture and which did not fully fit the standard representational politics of independent India's majoritarian democracy. (p. 105-106)

This "culturization" reduced the heterogeneous people known as adivasis to an embodiment of atavism, a binary of "the space for urban civic existence" (p. 113-114). The cultural 
quietism purported by a plastic adivasi consciousness glossed over the real struggle and problems of non-elite adivasi populace.

From the 1940s to the first decade of the twenty-first century, Munda, Santhal, Oraon and many other adivasi communities have been protesting against the large-scale 'development' projects initiated by the state as well as corporate establishments-the dams, factories, power plants and mines-as these projects increased their impoverishment, land-alienation and displacement. According to a Planning Commission report, projects of this sort displaced 21.3 million people in total from 1951 to 1990 in Andhra Pradesh, Bihar, Gujarat, Maharashtra, Rajasthan, Madhya Pradesh and Orissa, among which 40 per cent were tribals (Xaxa, 2008, p. 9). The report also shows that around 80 per cent of tribal children were anaemic and 50 per cent were underweight. In 1993-1994, 51.14 per cent of the tribal people came under the BPL category, as per the Ministry of Tribal Affairs (p. 9). In the colonial period, the so-called tribes were progressively dispossessed, lumpenised and criminalised by the British government. After 1947, despite promising governmental measures to improve their socio-economic condition-such as "devolution of governmental power to local panchayats to facilitate local governance and selfreliant local communities" and the PESA Act-marginalisation of adivasis continued, and as a result, violent resistant movements backed by the Maoists, CPI (ML) and the like emerged in the affected areas (p. 147).

Moreover, as Kaushik Ghosh points out, in the 1990s, there emerged a transnational 'indigenism' which promised to favour the cause of the adivasis but was actually detrimental to the historical fight for their rights put up by subaltern adivasis in India (Ghosh, 2006, p. 505). The transnational welfare bodies like the Working Group on Indigenous Populations (WGIP), a subsidiary body under the United Nations (UN), reconfigured the political processes initiated by the local subaltern adivasis in such a way that ultimately, the position of subaltern adivasis was jeopardised (Ghosh, 2006, p. 501-506). One must also note that in the 1980s a novel intellectual concern with indigeneity emerged with this transnational discourse. This intellectual concern visible primarily in academia proclaims to protect adivasi rights through preservation of environment against the onslaught of the rising corporatocracy in post-colonial nation-states; but it has its own pitfalls. Ajay Skaria comments upon the shortcoming of this new intellectual salvage:

I am, of course, sympathetic to much of the politics accompanying the image of the alternative savage, and certainly we do need to fight the violence of modern South Asian nation-states against adivasis. But surely we also need to pay attention to the weapons and images we fight with. We need to recognise that we are often being complicitous with a masculinist colonial discourse, that we are primitivizing and essentializing adivasis in an attempt to think through some of our real problems with postcolonial modernity. And however laudable and admirable our politics, there is a profound disrespect and violence involved in these strategies. (Skaria, 1997, p. 742-743)

Because of a powerful self-fashioning (as a purely atavistic, homogeneous, ethnic community) by elite adivasi leaders, and the success of the iconic Jharkhand movement, an entire non-elite population got reduced to a conflicted cultural imaginary: on the one hand, the adivasi was a "rebel", a threateningly disintegrative force vis-à-vis the nation-statist ideology, and thus it was situated outside the discursive paradigm of modernity; on the other hand, the adivasi was primitive and animist, a noble savage, and thus it was situated inside the discursive paradigm of modernity as a cultural artefact that requires preservation and 'proper' exhibition (p. 507). 
It can therefore be stated that the dispossessed and exploited adivasis thus attain the status of what-in the Spivakian sense-can be called the 'subaltern'. Gayatri Chakravorty Spivak argues that since the subaltern is always 'represented' by and in the elite, dominant discourses, the actual 'voice' of the subaltern is never 'heard', not even in the postcolonial critical enquiry initiated by the Subaltern historians. In her acclaimed essay "Can the Subaltern Speak?" Spivak draws upon the nineteenth-century colonial law and the ancient Hindu scriptural texts on widow self-immolation or sati in order to argue that the agency of the widow was always appropriated by these hegemonic discourses:

Between patriarchy and imperialism...the figure of the woman disappears, not into a pristine nothingness, but into a violent shuttling which is the displaced figuration of the 'third-world woman' caught between tradition and modernization. (Spivak, 1988, p. 306)

The peril of the non-elite adivasi is akin to that of the 'third-world women': "The subaltern is always framed as a quisling or as a resistant. Its own voice is never heard" (Maggio, 2007, p. 425). Likewise, the adivasi identity is always framed by colonial and neocolonial discourses. The colonial state labelled them as insurgent, animist, criminal and bestial 'tribe' (as opposed to the Hindu caste). The dominant anticolonial nationalists considered them as an embodiment of a pre-colonial purity. All this paved the way for the post-independence labelling of the adivasi as the autochthon who can either be the reluctant subject of 'development' (to be curbed or eliminated) or be a cultural artefact (to be preserved and exhibited). Amidst this colonial and neocolonial framing of adivasis (epistemology), the actual struggle and subjecthood of a subaltern population (ontology) is lost; their voice muted.

Before analysing Hansda's novel, one must note that the Indian middle-class artistic milieu, by and large, reeks of underrepresentation as well as misrepresentation of the adivasi. As Anshul Avijit succinctly argues, many notable artists of Bengal of the early twentieth century used Santhals as their instruments of critique against colonial modernity as they imbued them with an "Arcadian docility" (Avijit, 2018, p. 331). These artists, in their creative attempts, constructed a romantic image of Santhals and made it a part of their resistance to colonial teleology; but, in so doing, they ended up objectifying the group as a monolithic cultural artefact. In accordance with Prathama Banerjee's argument about representations of the adivasi in Mrigaya (1976) by Mrinal Sen and Agantuk (1991) by Satyajit Ray, it can be said that these post-independence, Bengali, middle-class auteurs unwittingly reinvigorated the romaticisation of tribals initiated by the preindependence artists of Bengal (Banerjee, 2006, p. 113). Moreover, Debasree De aptly points out the ways in which adivasi men and women were objectified as embodiments of a coveted primordial sensuality in the imagination of the Bengali bhadralok through the works of Rajnarayan Basu, Sanjib Chandra Chattopadhyay, Bankim Chandra Chattopadhyay and Bibhutibhushan Bandyopadhyay (De, 2018, p. 237-240). Amidst this widespread romanticisation, Mahasweta Devi, Anita Agnihotri and Bhaskaran seem to posit alternative representations of adivasis (De, 2018, p. 240-242, Turner, 2012, p. 327-337; Collu, 1999, p. 50-56). Notably, "Draupadi" (1978), "Doulati the Bountiful" (1993) and Chotti Munda and His Arrow (1980) written by Mahasweta Devi fulminate against the exploitation of indigenous people problematising the elitist gaze at the subaltern adivasis. However, it might be a matter of debate that whether Devi's literature of protest embodied by Dopdi of "Draupadi", the subaltern adivasi woman whose nudity threatens her oppressor at the end of the story, somewhat unwittingly consolidates an ethnic stereotype in which the adivasi is a threat to the 'civilised'. Of late, publisher and activist Ruby Hembrom with her publishing and archiving house named 'Adivaani' has been promisingly working towards a postcolonial 'rediscovery' and 'recuperation' of 'adivasi' lived experience and 
artistic productions; and this creative endeavour towards decolonisation of 'indigeneity' is laudable. However, it might be speculated that the paintings of Santhal men and women in her book titled Disaibon Hul (2014), in which Ruby Hembrom along with Saheb Ram Tudu primarily depict the Santhal Rebellion of 1855 through illustrations, inadvertently somewhat reiterate the monolithic images visible in paintings of nineteenth-century colonialists and twentieth-century Indian middle-class Bengali artists (Hembrom and Tudu, 2014). ${ }^{i}$

\section{Analysing Hansda's novel and decoding his politics of representation}

Fictional works of Hansda Sowvendra Shekhar are infused with his experience as a medical officer in Pakur, Jharkhand. His medical pursuit impels him to explore the predicament of adivasis through a sharp focus on diseases and malnourishment. His collection of short stories titled The Adivasi Will Not Dance (2015) deals with subaltern-adivasi concerns ranging from wistful ruminations over the loss of land and culture brought forth by the corporate establishment of factories and dams, to a diatribe against the neocolonial state. The book was banned by the Government of Jharkhand in 2017 for its allegedly 'bad' portrayal of Santhal women; but Hansda in his defense proclaimed that what he represented was reality (Datta, 2017). If the short story "November Is the Month of Migrations" disturbingly upholds the perils of displacement that changed the habitat as well as the livelihood of the people of a colliery region, the concluding narrative "The Adivasi Will Not Dance" registers an angry culmination of the sense of loss of habitat, livelihood, culture and agency that metamorphoses into a subversive rant. His novel The Mysterious Ailment of Rupi Baskey narrates a tale of a region that falls in the 'adivasi' area, more precisely, in the 'Santhal Pargana' (administrative divisions in Jharkhand: Godda, Deoghar, Dumka, Jamtara, Sahibganj and Pakur). The characters come from different walks of a Santhal community that reside primarily in the fictional Kadamdihi which has been modelled on Kishoripur of the Chakulia block of Jharkhand's East Singbhum district, the ancestral place of Hansda. Evidently, his work is a testimony of his belief that

[F]iction cannot be kept apart from anything that surrounds you, be it life or activism or anything. All that happens around you, all that influences your life, somehow show in your writing. Your politics, your dissent, your beliefs, they all show in your writing. So activism may seep into your writing and it is totally natural. (Hansda, personal communication, April 12, 2019)

As Satyen K. Bordoloi points out in a review of The Mysterious Ailment of Rupi Baskey, Rupi's illness under Gurubari's spell is a metaphor for the suffering of adivasis under non-adivasi hegemony; and the dust jacket of the book provides a key to this interpretation:

The aboriginal tribals of India birthed their civilization amidst a lot of pain and struggle. Then after, the rest of the civilization and its rival in resources, city-settlers, gave them an illness that was like the alakjari vine which engulfs the tallest, greenest trees of the forest and sucks their hearts out. Now the tribal people, once the strongest in the world, live out their days in the backyard of human consciousness, and their life dissolves into an incomprehensible ruin around them. (Bordoloi, 2014)

Likewise, Rupi gives birth to her children amidst a lot of pain, and then receives an illness from Gurubari, the alakjari vine of her life. Eventually, she is found lying on a cot in the backyard, on the fringes of her house (Bordoloi 2014). As indicated in the previous section, to obtain their own cultural distinctiveness, adivasis ended up being a victim of a neocolonial cultural quietism. 
The discourse of indigenism engineered by the elite adivasi leaders and transnational welfare organizations, appeared to empower subaltern adivasis, but eventually jeopardised their position. Thus in their attempt to secure their ground, they were relegated to a precarious position in the prevailing paradigm of modernity. Similarly, Rupi's strength, her physique, turns into her weakness. Her body betrays her under the spell of Gurubari. Her mysterious ailment thwarts her work as well as her movement (Hansda, 2014, p. 144). Her ailing body demands continuous care from her family members. Likewise, it might be affirmed that the marginalised adivasi always seems to require some sort of paternalistic governance-be it from colonial adminsitration, postcolonial government or elite adivasi leaders. From a strong woman who could hunt and cultivate, Rupi becomes a cripple who needs help all the time. This transformation can be seen as a representative of the metamorphosis of a sentient being into a cultural imaginary called the adivasi. As the ailment of Rupi is a mystery, the misfortune of adivasis remains unknown to the privileged Indians. The apparently individual, microcosmic agony of Rupi is thus symbolic of the communal, macrocosmic loss and misfortune of the subaltern population of India.

From the above reading of the novel, one may deduce that Hansda's depiction of the Santhal showcases victimhood as the only form of adivasi subjectivity. It can be contended, however, that such a view is a disservice to the merit of the novel and to the author. First, the author who elsewhere asserts "The Adivasi Will Not Dance", through the rant of the troupe master Mangal Murmu in the titular short story of the collection, is more likely to resist oppression than to eulogise victimhood. Moreover, the novel is much more than a postcolonial allegory of victimhood of an oppressed ethnic group in India. If Rupi's illness represents suffering of subaltern adivasis, her fight and endurance are indicative of a subaltern resistance. Throughout the narrative she grapples with her illness with indomitable spirit. Her defiant and enduring subjecthood is evident in her assertion "Nothing will happen to me," and in her constant endeavours to join the workforce in Kadamdidhi (p. 151). Besides, one must note Hansda's reply to a question (asked by the author of this article) about the symbolic dimension of Rupi's struggle: "I did not intend Rupi's story to be symbolic of anything" (Hansda, personal communication, 2019). This succinct statement of Hansda seems to indicate that Rupi's story is more than a symbol. Therefore, as the article argues, what is worth discussion is the ways in which Hansda shows how the so-called Santhal/adivasi self forms and reforms through its negotiation with colonial and neocolonial capitalist modernity in The Mysterious Ailment of Rupi Baskey. In addition, it would be shown in the article, the narrative centring Rupi gains power from a paradox: Hansda simultaneously presents his characters as magical and real; mysterious and vivid. In so doing, he seems to subvert, as it would be argued in the article, the colonial/neocolonial, elitist ideology that discursively reduced complex adivasi identities into monolithic images.

As it has been shown in the previous section, many artists in India unintentionally reinvigorate colonial/neocolonial ethnic stereotypes about adivasis, despite aiming at a noble recuperation of oppressed voices. In order to debunk the colonial and neocolonial romanticisation of his community, Hansda too runs the risk of creating a counter imaginary, a reverse stereotype: an image of the Santhal/adivasi that challenges the dominant ones but, in so doing, objectifies the actual human beings whom it proclaims to represent as they are. However, it can be contended that The Mysterious Ailment of Rupi Baskey constantly runs counter to romanticisation of the adivasi/Santhal lived experience. For instance, in several occasions, Hansda seems to underscore the prejudices that prevail in Santhal villages. Through a cross-section of a Santhal community, Hansda exposes the clan hierarchy and social stereotypes that exist among Santhals. The narrator's commentary on social roles of various clans among the Santhals of Kadamdihi introduces the reader to the rigid and discriminatory clan hierarchy that exists within 
Santhal community: the Hansdas are the most prosperous ones so they lead villages; the Marndis are priests; the Murmus organise nuptial unions; while the Tudus are artists or poets (Hansda, 2014, p. 13). In addition, the narrator's attitude towards Sabar men and women reeks of social discrimination: "So primitive were the Sabars reputed to be that they apparently had no language and no religion.... [and] once Sabars had enough money or education they forgot where they came from" (p. 116). Similarly, Hansda debunks the patriarchal ideology entrenched within the fabric of Santhal community when the narrator proclaims in the story that "Amongst Santhals, women's bodies are not considered appropriate vessels to receive gods" (p. 25), and "it is a taboo for women to become mediums [for spirits]" (p. 172). In addition, as witchcraft predominates the narrative, it can also be argued that through the depiction of witches. Hansda critiques the social practice of witch-hunting and of social stereotypes, divisions and hierarchies that exist among Santhals. As Shashank Sinha maintains, witch-hunting can be construed as violent means through which "gender and social tensions" were resolved and gender discrimination institutionalised (Sinha, 2006, p. 133). In fact,

Denial of land rights, control over women's sexuality, prevalence of comprehensive taboo regimes, and absence of political representation, formed some of the many 'established traditions' in Chotanagpur. In the context of customary exclusion and discrimination, witchcraft constituted one of the limited ranges of available responses for women. It represented an act of resistance against an exploitative patriarchal structure: a fault-line along which social tensions could be articulated (p. 133).

Witchcraft often became a means to authority and respect for the socially marginalised adivasi women (Skaria, 1998, p. 89). It might then not be an exaggeration to claim that when the witches, Gurubari, Dulari and the naikey's wife, cast their spells upon the villagers, they curiously remind the reader of the age-old intra-ethnic oppression and marginalisation of Santhal women by men. The narrator's concern that "Kadamdihi was no longer safe" under dahnis or witches (Hansda, 2014, p. 180) is ironically a mark of justice for the historical gender oppression that Santhal women have been undergoing. Probably, the dystopic Kadamdihi rife with witches bears the implication that oppressive social customs and rituals have devastating backlashes. Thus the novel points at the flaws and factions within the Santhal community; and in this way, it upholds a nuanced depiction contrary to the widespread homogenisation and glorification of Santhals.

One also observes that Hansda does not portray the Santhal community as a homogeneous bloc isolated from the 'outer world'. He places them amidst continuous interactions and negotiations with other communities and with the socio-economic changes in the wake of capitalist modernity. For instance, the feud between the lower-caste Hindus (namely Kunkals and Kamars) and the Santhals of Kadamdihi indicates a seething hierarchy that may surface between dalits and tribals:

The Kamar and the Kunkal belong to the lower rungs of the caste ladder of the Hindu religion. But both used to consider the Santhals of Kadamdihi impure and uncivilized as they ate cow and pig meat, drank handi and paura, and practised polygamy. (Hansda, 2014, p. 14)

Moreover, one must note the ways in which the development of Rupi's character is framed by both modernity and 'adivasi culture'. Her early life is dynamic and apparently idyllic: brought up in Tereldihi, a village in the hills, Rupi is fond of hunting sparrows with slingshots (p. 2). However, Rupi, despite being an adivasi villager of Tereldihi, who hunts and cultivates, uses "the famed Bottle-brand soap of Chakuliya" (p. 3), and later, the reader is informed that Chakuliya is "the nearest big town and railhead from Kadamdihi" (p. 81). Thus, from the outset, Hansda avoids 
unidirectional framing of his Santhal protagonist: Rupi's self is caught on the cusp between the rural Tereldihi and the semi-urban, semi-industrialised Chakuliya.

After marriage, she is brought down to the plains, the village named Kadamdihi. Even then she "knew no rest" (p. 3). The new bride Rupi then goes to Nitra to stay with her husband Sido. Notably, Nitra is a more industrialised region: "Nitra was one of the few villages which already had electricity" (p. 93). Besides, her adversary Gurubari, who practises "dahni bidya" and inflicts the illness on her, comes from Jirapara near Chakuliya (p. 12). Thus the text indicates that Rupi's contact with certain contours of modernity (such as the industrial soap and the railways) starts at a very early stage of her life and continues after her marriage.

Also, the reader comes to know that as Rupi gradually goes away from Kadamdihi, Rupi's body aches, and most of the time she feels weak (p. 6-7). Even her return to Kadamdihi does not help. Gradually, she is seen "on the cot under the dogor tree" (p. 7). This change from movement to stasis-Rupi, the strongest female labourer, losing her strength and failing to perform even household works-might be said to approximate the discursive metamorphosis of the dynamic heterogeneous population (known as 'tribes' or 'adivasis' or 'indignes') into static one-dimensional cultural artefacts, a process engineered by colonial and neocolonial power structures. It can be argued that as Rupi continuously tries to return to work (dynamism), Hansda labours to debunk the static image of Santhals, and that his attempt at the destabilisation of monolithic representations of Santhals is visible in Rupi's encounters with capitalist modernity. That is why Rupi's journeys (by bullock cart, bus and train) to Chakuliya and Nitra are punctuated by an imagery of revamped or fractured relics of capitalist modernity such as the chimneys of the copper factory, the onomatopoeic "dhokor dhokor" of the railway engine, ruins of the huge aerodrome, rice mill and so on (p. 84-9o).

These relics of modernity are extremely significant as they encapsulate the negotiation of adivasis with the soi-disant non-adivasi interventions into the adivasi hinterland-be it the colonial governmentality, the money-lending dikus or the neocolonial mining projects, dams and factories. Adivasi's identity, like any identity, is not monolithic; it is in a state of flux as it negotiates old and new ways, tradition and modernity. Similarly, Rupi's self undergoes a continuum of negotiations between the traditional and the modern. Her ruminations on her past life, when she looks through the window of the train, seem poignant and indicative of her perturbed self:

This was her first journey outside home and a new world was unfolding before her eyes. There were so many things she was seeing for the first time and she wanted to know about them all. But how could she ask? Would so much curiosity in a new bride be considered proper? What would her husband think? These thoughts kept her silent, and the silence soon became unbearable. (p. 87)

Moreover, one must notice the ephemerality of the scenes that Rupi witnesses: “'Oh!' Rupi caught a fleeting glance before the building slipped out of sight" (p. 85), "Rupi caught a glimpse of the chimneys soon after the train pulled out of the Ghatshila Railway Station" (p. 87), "She wished the train could move backwards. She wanted to see the Subarnarekha again" (p. 87-88), "Rupi could only catch the name of the place and nothing else" (p. 89). It can be contended that this transience is symptomatic of Rupi's psychological struggle to come to terms with the new way of the world. Amidst this rapid transition, she longs for the past comfort and familiarity, and probably this yearning is evident in her wish to see "the train retrace its track" and "the Subernarekha to return" (p. 88). 
Rupi's anxiety is thus revealed in her journeys to the semi-industrialised Chakuliya and Nitra. She constantly negotiates the socio-economic mutations that her new life brings forth. As she wonders "Why did women like Putki and Della, who belonged to prosperous families, ever need to work in a factory?" (p. 86), and observes that the anonymous landlord of Sido at Nitra, is a "majhi" (leader/headman) by his ethnic identity and a prosperous farmer, yet works as a labourer at the mines (p. 96-97), she comes to terms with this new world, a new socio-economic order, that is alien to the remote and 'backward' Tereldihi and Kadamdihi in which agriculture and animal husbandry are still respectful vocations. It must also be noted that Hansda is keen to draw a contrast between the illiterate Rupi and the school master Sido: knowing that Sido's name is written on the board of the school building,

"Rupi could only nod her head. She was proud of the man she was married to.... I am such a fool! She thought to herself, and looked longingly at her husband who grinned as he stepped down from the veranda". (p. 91-92)

All these signs of anxiety add to the complex picture of Santhals which is fraught with intra-ethnic, gender and class hierarchies-a picture of a community which is also caught in the vortex of modernity.

Furthermore, it can be argued that the purpose of employing the postmodern narrative device namely magical realism in the novel is to underscore the ontological complexity of the Santhal way of life. Magical realism naturalises or normalises the supernatural (Warnes, 2009, p. 3). The limits of realism are expanded by the magical elements as the realist mode of narration contextualises the supernatural with the help of familiar, plausible elements and/or events (Bowers, 2004, p. 21). Magical realism is then a literary imaginary where "the realism of the real is permeated by magic just as the world of the magical is underpinned by the real" (Hart, 2005, p. 4). Having its genesis in Frantz Roh and Alejo Carpentier, magical realism achieved its canonical status with the publication of Gabriel García Márquez's magnum opus One Hundred Years of Solitude (1967) (Hart, 2005, p. 3; Bowers, 2004, p. 32; Aldea, 2011, p. 1). If Marquez has muddled the distinction between the European/'rational' and the Latin-American/'irrational' by employing magical realism, Salman Rushdie developed a subversive discourse of ambivalence by clashing postmodern and postcolonial representational codes together in Midnight's Children (1981). In Rushdie, the postmodern ambivalence centring one's identity has postcolonial reverberations (Kluwick, 2011, p. 2). That the first significant memory of the protagonist Saleem Sinai is his being an apparition is not only magically real but also simultaneously postcolonial and postmodern: he is "the apparition of a colonial identity stranded in the netherland of subalternity" as well as an embodiment of the quintessentially postmodern characteristic of being in (un)making (Hart, 2005, p. 8).

Indeterminacy and subversion get closely linked with magical realism in African literature as well. Writers like Ben Okri draw upon the rich repository of African myths to create "ambiguous fictional spaces" which take issue with colonial discourses (Cooper, 1998, p. 216). Magical realism thus becomes much more than a narrative/aesthetic strategy in writings of Marquez, Rushdie, Okri and others: it gets intertwined with a materialist politics of power that pertains to the complex equations of dominance and insubordination in terms of class, race, gender and so on. If for Marquez and Rushdie it is the Caribbean and Indian specificities that shape their magical realism respectively, for Okri it is the Yoruban/African folklore that underpin the marvellous real (Warnes, 2009, p. 151-152). All of them employ magical realism to address the complex postcolonial issues which are contingent on specific historical and cultural factors. 
Hansda's magical realism is informed by Santhal cosmology and orature (folklores, riddles and myths). Witchcraft and the 'evil eye' are ingrained in the belief system of subaltern Santhals, and in that of almost all adivasi communities in India (Sinha, 2006, p. 127; De, 2018, p. 213). Probably, that is why Hansda says that he believed that witches and magic are to be in the narrative of Rupi (Hansda, personal communication, 2019). As mentioned earlier, Rupi's ailment is a result of Gurubari's spell (Hansda, 2014, 37, p. 142). This dahni-bidya is represented in a matter-of-fact way throughout the narrative. For instance, when the first wife of Somai-haram, the Older Somai-budhi, seems to be affected by witchcraft, he seems anxious about the identity of the witch, not about the possibility of the existence of dahnis (p. 32). That "Santhal men drink haandi, Santhal women practise dahni-bidya" are part of the commonplace knowledge in Kadamdihi (p. 37). The narrative is replete with vivid portrayals of supernatural creatures namely the dahnis and the Dhonkundra-bhoot, an impish ghost (p. 34-35, 58-59, 79, 8o, 82, 113-114, 133, 138, 142, 195). Gurubari is one of the witches. Apparently, she is a wife of a Santhal school teacher and a mother of two daughters. However, once Rupi catches her casting a spell over Jaipal, Rupi's eldest child (p. 113-114). The flickering light and the sudden change in Gurubari's tone subtly indicate her association with the supernatural. They are suggestive of her alternative self constituted by her witchcraft.

Rupi pushed the door open. What she saw inside wasn't exactly alarming but it didn't seem normal, either. Before her was Jaipal, fast asleep on a mat. Gurubari was sitting before Jaipal, her back to the door. Her hair was open, uncombed, and in a wide tangle. There was no harkane lamp in sight, yet there was light. The lamp must be somewhere in a corner where I can't see it, thought Rupi, even though the glow in the room seemed to emanate from a crackling fire, not from a steady flame confined within the glass of a lamp. (p. 113)

The scene is a hallmark of Hansda's dexterity in blending the marvellous with the real. The idea that what Rupi saw inside was neither "alarming" nor "normal" points at a curious liminality that empowers Hansda's representational politics; and this interstitiality destabilises both the real and the magical representational strategies thereby justifying the oxymoronic sense of 'magical realism'. The textual play between the marvellous and the real, which is set in motion by the narrator's voice enveloping Rupi's thoughts, is attuned to the object of its representation - the complex lives of Santhals in Kadamdihi, and that it indicates the author's awareness of the colonial/neocolonial representational hegemony over Santhals/adivasis in India. It might be argued that since the magical elements of the novel have their genesis in subaltern-adivasi tradition (folklores, riddles and myths), and the genre of novel has a strong connection with the rise of bourgeois realism in the west, The Mysterious Ailment of Rupi Baskey: A Novel attains a hybrid status as it fuses the magical with the real: it is neither an 'adivasi folklore/myth' nor a 'western novel'; it is a narrative of Rupi. Makarand Paranjape argues that India's encounter with the west went through various phases, and that one of these phases was marked by a curious ambivalence in which India neither completely acquiesced to nor completely rejected the westthis state of interstitiality and hybridity is what Paranjape calls "non-subject" (Paranjape, 2009, p. 31). Therefore, it can be stated that by blending the marvellous (adivasi tradition) with the real (western realism) Rupi's story becomes a non-subject that does not confirm to any well-defined creative tradition.

In addition, magical realism becomes an apt literary technique because its constitutional instability and ambiguity approximate the difficulties in representation of the ontological complexities of subaltern indigenes. Like the works of Okri, Marquez and Rushdie, Hansda's 
magical realism is political. Through the artistic paradox of reality and magic, Hansda's novel becomes self-conscious and self-referential constantly undercutting its verisimilitude. ${ }^{\text {iii }}$ Rabindranath Tagore's poem "The Kopai" achieves a similar goal in depicting a Santhal woman:

In this Santal woman ... the poet found a language, which, like music, did not make itself redundant by reducing itself to a mirror of reality. In fact, this language did not claim to represent reality at all. Rather, it sought, through poetic intervention, to transform the otherwise trivialized reality of congested and colonized everyday time. (Banerjee, 2006, p. 122)

Through magical realism, Hansda's novel not only subverts its claim to truth but also highlights the non-representational nature of Santhal lives. This artistic paradox of Hansda is political because it enables the novel to isolate itself from other hegemonic representations of indigenes, and to avoid construction of any homogenous image of Santhals. As it has been mentioned before, the work foregrounds the struggle of Rupi Baskey with her mysterious ailment. In fact Hansda himself claims to centralise Rupi's struggle in the story (Indian Writers Forum, 2017; personal communication, 2019). By foregrounding Rupi's fight and endurance, Hansda therefore underscores her agency and dignity. This articulation of Hansda can be read as his attempt to show how the subaltern can fight with dignity even when everything is out of her hands. Therefore, it can be stated that Rupi's narrative seeks, through artistic intervention, to transform the real situations of subaltern adivasis in India which have been colonised by oppressive power structures. At the end, in the chapter significantly titled "The Cure? Well, Almost", Rupi straddles dream and reality, cure and disease, emancipation and suffering: she seems "free of suffering" but the scene also appears to be her dream (Hansda, 2014, p. 208). Thus the novel ends with an artistic ambivalence where the subaltern 'almost' gets cured, and it is in this enigma of half-truth/half-dream that the subaltern can find her agency. When the 'real' is colonised by the elite, the 'magical' intervenes and creates a subversive liminality. In this way, Hansda seems to envisage what Homi Bhabha would call the 'Third Space', a discursive field in which "the meaning and symbols of culture have no primordial unity or fixity" (Bhabha, 2006, p. 157). This subversive locale, as Bhabha locates this in Frantz Fanon's idea of revolutionary cultural and political change in a postcolonial scenario, questions the legitimacy of established categories and meaning. The novelistic world of Hansda appears to be a critical departure from other monolithic images of adivasis questioning the legitimacy of the colonial and neocolonial frameworks that essentialise the subaltern adivasi.

\section{Conclusion}

Colonial discursive formations and administrative strategies oppressed the subaltern communities which fell under the category of tribe. In post-colonial India, the situation of these people has remained largely unchanged, if not been worse. They have been stereotyped and marginalised either as reluctant subjects of the nation-state, hence to be curbed, or cultural artefacts to be preserved. With a new interest in adivasi rights that emerged with the rise of a transnational discourse on indigeneity in the 1990s, there have been inadvertent attempts at reinvigorating the ethnic stereotypes which proliferated in colonial India. Unfortunately, many Indian intellectuals and artists have unwittingly endorsed and perpetuated this reductivism. However, as it has been argued in this article, Hansda neither creates any homogeneous image of Santhals nor foregrounds the victimhood of the subaltern community; instead, he offers a nuanced picture of a Santhal community which is fraught with internal conflicts as well as 
external threats. In so doing, he undercuts the grand narrative in which the adivasi is a cultural imaginary, a signifier of atavism, wildness and/or victimhood. The narrative of Rupi attains the status of the "non-subject" as it hinges on the tension between authenticity and falsehood, believable and unbelievable, the real and the magical, and in this way, it hybridises its generic identity and destabilises its claim to truth. Instead of proclaiming to create an 'authentic' picture of Santhals/adivasis, the novel thus artistically seeks to transform the otherwise colonised condition of indigenous communities in India. The subaltern represented in Hansda can 'speak' through her struggle with a mysterious ailment. Thus the novel appears to be a critical departure from colonial and neocolonial representations of Santhals/adivasis creating a 'Third Space' which is marked by a subversive ambivalence and interstitiality. In this way Hansda's representational politics interrogates the dominant discourses on indigeneity in India.

\section{Notes}

${ }^{\mathrm{i}}$ Anshul Avijit's work is a comprehensive critical commentary on these colonial and native middle-class stereotypes of Santhals (Avijit, 2018).

ii The words of Hansda quoted as personal communication have been taken from the email conversation between him and the author this article (dated April 12, 2019).

iii Probably Hansda, despite being an 'insider' to Santhals, is aware of his 'distance' from the subalterns of the community. This distance is manifold. First, he uses English (elitist language), and then selects the genre of novel (elitist genre) to tell a story about subaltern Santhals. Above all, he is an English-educated doctor, and therefore an elite in comparison with people like Rupi, Khorda, Putki and so on-and probably that is why, he renders his art self-conscious and self-referential. It cannot be said that Hansda or any author who uses elitist language and genre to represent the subaltern shall be able to erase the socioeconomic distance between their elitist position and their object of representation. However, it might be contended that Hansda seems to undermine the elitism of English language. As he states in one of his interviews, Hansda uses original, non-English words when he thinks that the English equivalent would not suffice (Indian Writers Forum, 2017). In The Mysterious Ailment of Rupi Baskey, Hansda frequently uses Santhal dialect adding to the texture of his representation as well as undermining the elitism of English language (Hansda, 2014, p. 47-51). However, it is beyond the scope of this article to determine the degree of this undermining. One may explore the language of the novel in terms of the famous 'language debate' between Ngugi wa Thiong'o and Chinua Achebe for that matter.

\section{Acknowledgement}

The author of this article is grateful to Hansda Sowvendra Shekhar for his meticulous, insightful email responses; to Dr. Debapriya Goswami for her scholarly inputs; and to the administration of Durgapur Women's College for enabling access to the INFLIBNET repositary maintained by the MHRD, India.

\section{References}

Aldea, E. (2011). Magical Realism and Deleuze: The Indiscernibility of Difference in Postcolonial Literature. London: A\&C Black.

Avijit, A. (2018). From 'Savages' to 'Saviours': Genealogy of Santal Portrayal in Colonial Modernity. In L. Choukroune \& P. Bhandari (Eds.), Exploring Indian Modernities: Ideas and Practices (pp. 303-334). Singapore: Springer. 
Banerjee, P. (2006). Culture/Politics: The Irresoluble Double-Bind of the Indian Adivasi. Indian Historical Review, 33(1), 99-126. https://doi.org/10.1177/037698360603300106

Banerjee, P. (2016). Writing the Adivasi: Some historiographical notes. The Indian Economic E Social History Review, 53(1), 131-153. https://doi.org/10.1177/o019464615619549

Bates, Crispin. (1995). 'Lost Innocents and the Loss of Innocence:' Interpreting Adivasi Movements in South Asia. In Andrew Gray, Benedict Kingsbury and R.H. Barnes (Eds.), Indigenous Peoples of Asia (pp. 109-119). Michigan: Association of Asian Studies.

Bates, C., \& Shah, A. (2017). Savage Attack: Tribal Insurgency in India. London: Routledge.

Baviskar, A. (2013). Written on the Body, Written on the Land: Violence and Environmental Struggles in Central India. In M. Rangarajan \& K. Sivaramakrishnan (Eds.), India’s Environmental History: Colonialism, Modernity, and the Nation (pp. 517-549). New Delhi: Permannent Black.

Bhabha, H. K. (2006). Cultural Diversity and Cultural Differences. In B. Ashcroft, G. Griffiths \& H. Tiffin (Eds.) The Post-Colonial Studies Reader (pp. 155-157). Routledge: New York.

Bordoloi, S. K. (2014). Take an inside look at the oldest people of India. Retrieved May 28, 2019

Bowers, M. A. (2013). Magic(al) Realism. London: Routledge.

Coates, K. (2004). A Global History of Indigenous Peoples: Struggle and Survival. New York: Palgrave Macmillan.

Collu, G. (1999). Adivasis and the Myth of Independence: Mahasweta Devi's “Douloti the Bountiful." ARIEL: A Review of International English Literature, 30(1), 43-57.

Cooper, B. (2012). Magical Realism in West African Fiction. London: Routledge.

De, D. (2018). A History of Adivasi Women in Post-Independence Eastern India: The Margins of the Marginals. New Delhi: SAGE Publishing India.

Dutta, S. (2017). Who is Hansda Sowvendra Shekhar, fighting a ban - The Hindu. Retrieved May $28,2019$.

George, A. (2016). Social Ferment in India. London: Bloomsbury Publishing.

Ghosh, A. (1993). Ideology and Politics of Jharkhand Movement: An Overview. Economic and Political Weekly, 28(35), 1788-1790. Retrieved from JSTOR.

Ghosh, K. (2006). Between Global Flows and Local Dams: Indigenousness, Locality, and the Transnational Sphere in Jharkhand, India. Cultural Anthropology, 21(4), 501-534. Retrieved from JSTOR.

Hansda, S. S. (2014). The Mysterious Ailment of Rupi Baskey: A Novel. New Delhi: Aleph.

Hansda, S. S. (2015). The Adivasi Will Not Dance: Stories. New Delhi: Speaking Tiger.

Hart, S. M. (2005). Magical Realism: Style and Substance. In S. M. Hart \& O. Wen-chin (Eds.), A Companion to Magical Realism (pp. 1-12). Woodbridge: Tamesis.

Hembrom, R. \& Tudu, S. R. (2014). Disaibon Hul. Kolkata: Adivaani.

Heredia, R. (2016). The Adivasi Other: Ethnicity and Minority Status. In M. Radhakrishna (Ed.), First Citizens: Studies on Adivasis, Tribals, and Indegeneous Peoples in India (pp. 126-150). New Delhi: Oxford University Press.

Indian Writers Forum. (2017). Writers Talk Politics | Hansda Sowvendra Shekhar in conversation with Souradeep Roy. Retrieved from https://www.youtube.com/watch?v=Q--N6uLjSsI

Karlsson, B. G., \& Subba, T. B. (2006). Indigeneity in India. New York: Kegan Paul.

Kluwick, U. (2013). Exploring Magic Realism in Salman Rushdie’s Fiction. London: Routledge. 
Maggio, J. (2007). “Can the Subaltern Be Heard?": Political Theory, Translation, Representation, and Gayatri Chakravorty Spivak. Alternatives, 32(4), 419-443. https://doi.org/10.1177/030437540703200403

Mehta, U. S. (1999). Liberalism and Empire: A Study in Nineteenth-Century British Liberal Thought. Chicago: University of Chicago Press.

Merlan, F. (2009). Indigeneity: Global and Local. Current Anthropology, 50(3), 303-333. https://doi.org/10.1086/597667

Paranjape. M. R. (2009). Altered Destinations: Self, Society, and Nation in India. London: Anthem Press.

Chakraborty, A. (2017). Examining Subalterneity in Hansda Sowvendra Sekhar' s “ The Adivasi Will Not Dance ." Postcolonial Text, 12(1), 1-15.

Rycroft, D. J., \& Dasgupta, S. (2011). The Politics of Belonging in India: Becoming Adivasi. London: Routledge.

Sanders, D. (1999). Indigenous peoples: issues of definition. International Journal of Cultural Property, 8(1), 4-13. https://doi.org/10.1017/So940739199770591

Sen, A. K. (2017). Indigeneity, Landscape and History: Adivasi Self-fashioning in India. London: Routledge.

Sinha, S. S. (2006). Adivasis, Gender and the 'Evil Eye': The Construction(s) of Witches in Colonial Chotanagpur. Indian Historical Review, 33(1), 127-149. https://doi.org/10.1177/037698360603300107

Sivaramakrishnan, K. (1999). Modern Forests: Statemaking and Environmental Change in Colonial Eastern India. London: Oxford University Press.

Skaria, A. (1997). Shades of Wildness Tribe, Caste, and Gender in Western India. The Journal of Asian Studies, 56(3), 726-745. https://doi.org/10.2307/2659607

Skaria, A. (1998). Hybrid Histories: Forests, Frontiers and Wilderness in Western India. New Delhi: Oxford University Press.

Spivak, G. C. (1988). Can the Subaltern Speak? In C. Nelson \& L. Grossberg (Eds.), Marxism and the Interpretation of Culture (pp. 271-313). Urbana: University of Illinois Press.

This is Our Homeland: A Collection of Essays on the Betrayal of Adivasi Rights in India. (2007). Bangalore: EQUATIONS.

Turner, E. (2012). An unfinished story: The representation of adivasis in Indian feminist literature. Contemporary South Asia, 2o(3), 327-339. https://doi.org/10.108o/o9584935.2011.649715

Warnes, C. (2009). Magical Realism and the Postcolonial Novel: Between Faith and Irreverence. London: Springer.

Xaxa, V. (2008). State, Society, and Tribes: Issues in Post-colonial India. New Delhi: Pearson Education India.

Dr. Amitayu Chakraborty (SCOPUS Author ID: 5564313860o) was awarded the Junior Research Fellowship by the UGC in 2012. He completed his Ph.D. in 2017 on Ngugi wa Thiong'o at the Department of English, Visva-Bharati, Santiniketan. His research interest includes postcolonial studies with special emphasis on the intersection among nationalism, ethnicity and gender. 